\title{
Article \\ Mitochondrial and Plastid Genomes of the Monoraphid Diatom Schizostauron trachyderma
}

\author{
Ewa Górecka ${ }^{1, *(\mathbb{D}}$, Romain Gastineau ${ }^{1, *}$, Nikolai A. Davidovich ${ }^{2}$, Olga I. Davidovich ${ }^{2}$, Matt P. Ashworth ${ }^{3}{ }^{(0)}$, \\ Jamal S. M. Sabir ${ }^{4}$ (D) Claude Lemieux ${ }^{5}$ (D), Monique Turmel ${ }^{5}$ and Andrzej Witkowski $^{1}$ (D) \\ 1 Institute of Marine and Environmental Sciences, University of Szczecin, Mickiewicza 16a, \\ 70-383 Szczecin, Poland; andrzej.witkowski@usz.edu.pl \\ 2 Karadag Scientific Station-Natural Reserve of the Russian Academy of Sciences, p/o Kurortnoe, Feodosiya, \\ 98188 Crimea, Russia; nickolaid@mail.ru (N.A.D.); olivdav@mail.ru (O.I.D.) \\ 3 Department of Molecular Biosciences, NHB, University of Texas at Austin, Austin, TX 78712, USA; \\ mashworth@utexas.edu \\ 4 Genomics and Biotechnology Research Group, Faculty of Science, King Abdulaziz University, \\ Jeddah 21589, Saudi Arabia; jsabir@kau.edu.sa \\ 5 Département de Biochimie, Microbiologie et Bio-Informatique, Institut de Biologie Intégrative et des \\ Systèmes, Université Laval, Québec, QC G1V 0A6, Canada; claude.lemieux@bcm.ulaval.ca (C.L.); \\ monique.turmel@bcm.ulaval.ca (M.T.) \\ * Correspondence: ewa.gorecka@usz.edu.pl (E.G.); romain.gastineau@usz.edu.pl (R.G.)
}

check for updates

Citation: Górecka, E.; Gastineau, R.; Davidovich, N.A.; Davidovich, O.I.; Ashworth, M.P.; Sabir, J.S.M.;

Lemieux, C.; Turmel, M.; Witkowski, A. Mitochondrial and Plastid Genomes of the Monoraphid Diatom Schizostauron trachyderma. Int. J. Mol. Sci. 2021, 22, 11139. https://doi.org/ 10.3390/ijms222011139

Academic Editor: Bartolome Sabater

Received: 1 September 2021

Accepted: 11 October 2021

Published: 15 October 2021

Publisher's Note: MDPI stays neutral with regard to jurisdictional claims in published maps and institutional affiliations.

Copyright: (c) 2021 by the authors. Licensee MDPI, Basel, Switzerland. This article is an open access article distributed under the terms and conditions of the Creative Commons Attribution (CC BY) license (https:/ / creativecommons.org/licenses/by/ $4.0 /)$.

\begin{abstract}
We provide for the first time the complete plastid and mitochondrial genomes of a monoraphid diatom: Schizostauron trachyderma. The mitogenome is 41,957 bp in size and displays two group II introns in the cox1 gene. The 187,029 bp plastid genome features the typical quadripartite architecture of diatom genomes. It contains a group II intron in the petB gene that overlaps the large single-copy and the inverted repeat region. There is also a group IB4 intron encoding a putative LAGLIDADG homing endonuclease in the $r n l$ gene. The multigene phylogenies conducted provide more evidence of the proximity between $S$. trachyderma and fistula-bearing species of biraphid diatoms.
\end{abstract}

Keywords: monoraphid; biraphid; diatoms; organellar; genome; multigene; phylogeny; LAGLIDADG

\section{Introduction}

The genus Schizostauron Grunow [1] represents one of the heterovalvar lineages of diatoms, where the two primary shells (valves) which make up the siliceous cell wall (frustule) have differing morphologies. In the case of Schizostauron, only one valve possesses raphe-longitudinal slits at the center of the valve which are involved in motility. Diatoms with this particular kind of heterovalvy are called "monoraphids", and the two valves are labelled by their raphe (RV) or lack of raphe (SV). Taxa in Schizostauron can be distinguished from other monoraphid genera by the morphology of the transverse thickening of silica at the central area of the RV called a stauros. The genus is typical of temperate to tropical marine littoral zones. Species in this genus have often been misidentified as the monoraphid genera Achnanthes or Cocconeis and have a complicated taxonomic history, which includes the registration of invalid holotypes [1-5].

Since the mid-19th century, monoraphid diatoms have been classified in a separate evolutionary lineage featuring one raphe-loss event [6-9]. Treated as such, all described monoraphid genera were assigned to the order Achnanthales, including Achnanthes (Achnanthaceae), Cocconeis, Campyloneis, Anorthoneis (Cocconeidaceae), Achnanthidium, and Eucocconeis (Achnanthidiaceae). Round et al. [8] later split the genus Achnanthes sensu lato into several genera based on the re-evaluation of distinctive and shared morphological characters. The presence of a heterovalvate frustule is a shared feature of all members of Achnanthes sensu lato, but other morphological characters such as the girdle, orientation 
and shape of areola, and valve outline or central area structure are highly variable. The process of transferring taxa from Achnanthes and Cocconeis sensu lato into morphologically appropriate, newly established genera has continued over the last three decades and multiple new genera have been established [10-16], but despite these revisions, small groups of achnanthoid and cocconeid taxa remain without detailed generic accommodation.

Molecular phylogenetic studies of the raphid diatoms have supported the idea of multiple switches to the monoraphid state. These studies have shown Schizostauron to be monophyletic and closely related to other monoraphid genera such as Astartiella, Madinithidium, Kolbesia, and Karayevia. However, these "stauroneid" monoraphid genera (so named because of the presence of Stauroneis Ehrenberg sensu stricto in the molecular clade) are not monophyletic with respect to the other monoraphid genera of the Achnanthaceae, Achnanthidiaceae, and Cocconeidaceae, suggesting that their monoraphid states evolved independently $[4,5,17]$.

Among other discriminating morphological characters, Schizostauron and monoraphid species included in the stauroneid have coaxial internal proximal raphe ends. This character is universal for the stauroneid genera Stauroneis, Craticula [8], and others that were recently studied using molecular data such as Fistulifera, Proschkinia, and Sternimirus [18-21]. In contrast, the genera in the Achnanthidiaceae and Cocconeidaceae feature proximal raphe ends bent internally into opposite directions [8,22]. The monoraphid species clearly need a revision of the higher-level taxonomy as they fail to form a natural group [22-24]. In addition, this could bring us closer to understanding the evolutionary origins of the different monoraphid genera, which would be the first step to elucidating the ecological or molecular selective pressures which lead to heterovalvy.

Here, we report the mitochondrial and plastid genome sequences of Schizostauron trachyderma (F.Meister) Górecka, Riaux-Gobin, and Witkowski, the first organellar genomes of a monoraphid diatom. These genomic data strengthen the phylogenetic position recently reported by Górecka et al. [5] and reveal that Schizostauron forms a clade within the Stauroneidaceae that is a sister to fistula-bearing Fistulifera and Proschkinia taxa. Several unusual features of the $S$. trachyderma organellar genomes will be discussed.

\section{Results}

\subsection{Microscopy}

Figure 1 illustrates the morphology of S. trachyderma, both in LM and SEM. The monoraphid morphology is apparent in comparing Figure $1 \mathrm{~d}, \mathrm{e}, \mathrm{i}(\mathrm{RV})$ with Figure $1 \mathrm{f}-\mathrm{h}$ (SV). The transverse stauros on the RV is particularly obvious in LM on Figure 1d,e.

\subsection{Mitochondrial Genome}

The 41,957 bp mitogenome of S. trachyderma (GenBank accession MZ520767) was retrieved with a coverage of 112X. It encodes the genes for 2 rRNAs, 22 tRNAs, and 35 proteins that include the two subunits of Nad11 and the conserved orf147 [25] (Figure 2). Two group II introns of $3348 \mathrm{bp}$ and $3325 \mathrm{bp}$ in length interrupt cox 1 and both code for putative reverse transcriptases (orf692 and orf679, respectively). The nad11- $a$ and nad11- $b$ genes are adjacent to each other and are separated by only a 139-bp intergenic sequence. Note that the exact position of the start codon of nad7 and rpl6 remains ambiguous. 

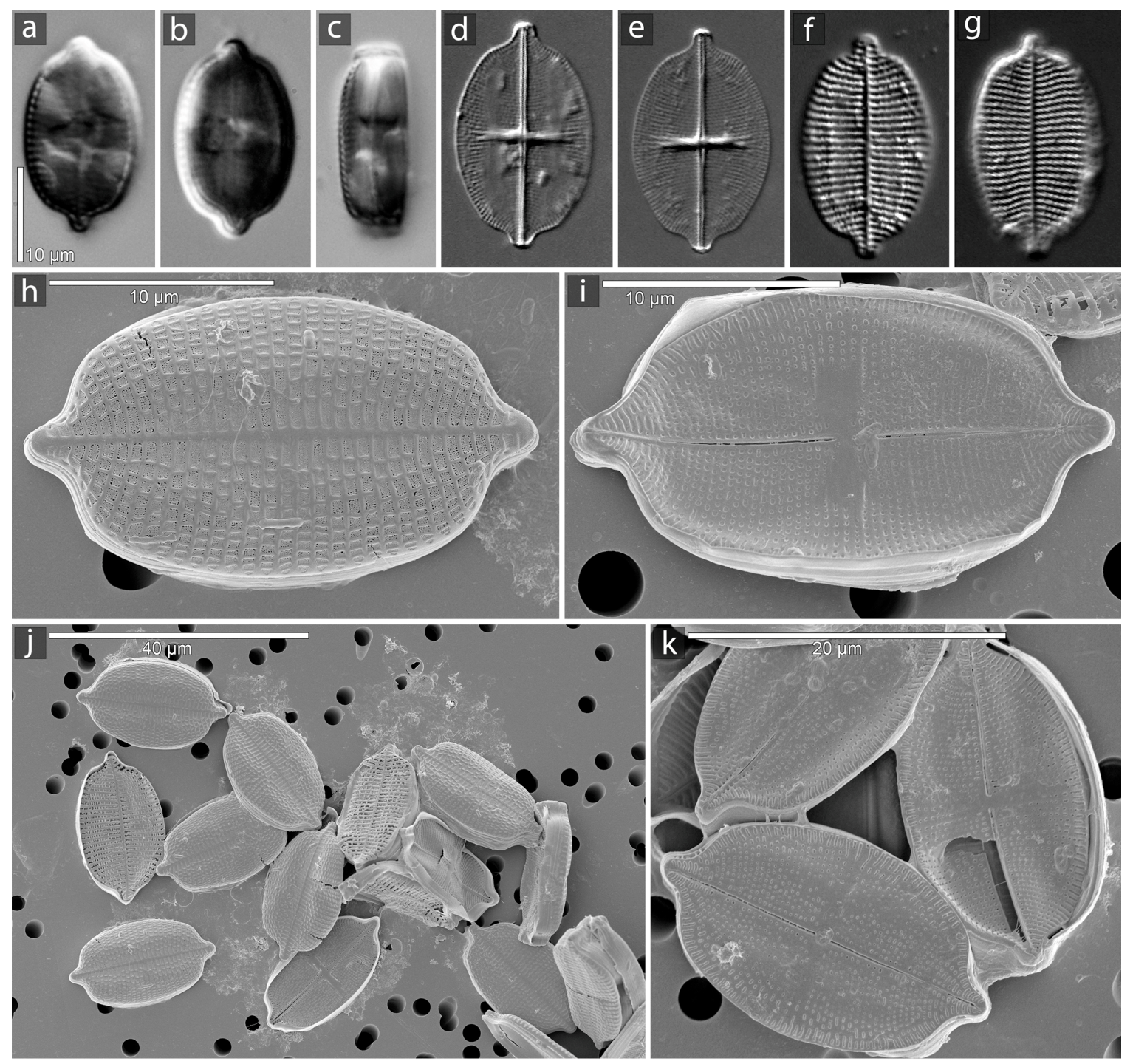

Figure 1. Light (LM) and Scanning electron microscopy (SEM) images of S. trachyderma. (a-c): live specimen with plastids. $(\mathbf{a}, \mathbf{b})$ : valve view. (c): girdle view. $(\mathbf{d}-\mathbf{g})$ : in LM. $(\mathbf{d}, \mathbf{e})$ : raphe valve. $(\mathbf{f}-\mathbf{g})$ : sternum valve. $(\mathbf{h}-\mathbf{k})$ : in SEM. (h): sternum valve. (i): raphe valve.

\subsection{Comparative Analysis of Diatom Mitochondrial Genomes}

The mitochondrial genome of $S$. trachyderma was aligned to those of five closely related species identified in the phylogenetic analysis described below. In total, five blocks of synteny were detected in the MAUVE alignment (Figure 3). The mitogenome of S. trachyderma revealed a unique arrangement of these syntenic blocks, with the adjacent syntenic blocks formed by $c o b$ and by cox3, nad3, cox2, nad7, nad 9 , and rps 14 rearranged to the opposite DNA strand as compared to the other five genomes. Two sets of colinear mitochondrial genomes were identified: (1) those of Berkeleya fennica Juhlin-Dannfelt and Didymosphenia geminata (Lyngbye) M. Schmidt; and (2) those of Fistulifera solaris S. Mayama, M. Matsumoto, K. Nemoto, and T. Tanaka, as well as Fistulifera saprophila (Lange-Bertalot and Bonik) Lange-Bertalot and Proschkinia sp. These two sets of colinear mitogenomes differ only with respect to the position of a large syntenic block containing atp6, rps10, rps8, rpl6, rps2, rps4, atp8, rps12, rps7, rpl14, rpl5, nad1, tatC, orf147, rps11, rpl2, rps19, rps3, rpl16, atp9, nad4L, nad11-a, and nad11-b. The significantly larger mitogenome of Proschkinia sp. is mostly explained by the presence of introns in cox1. 


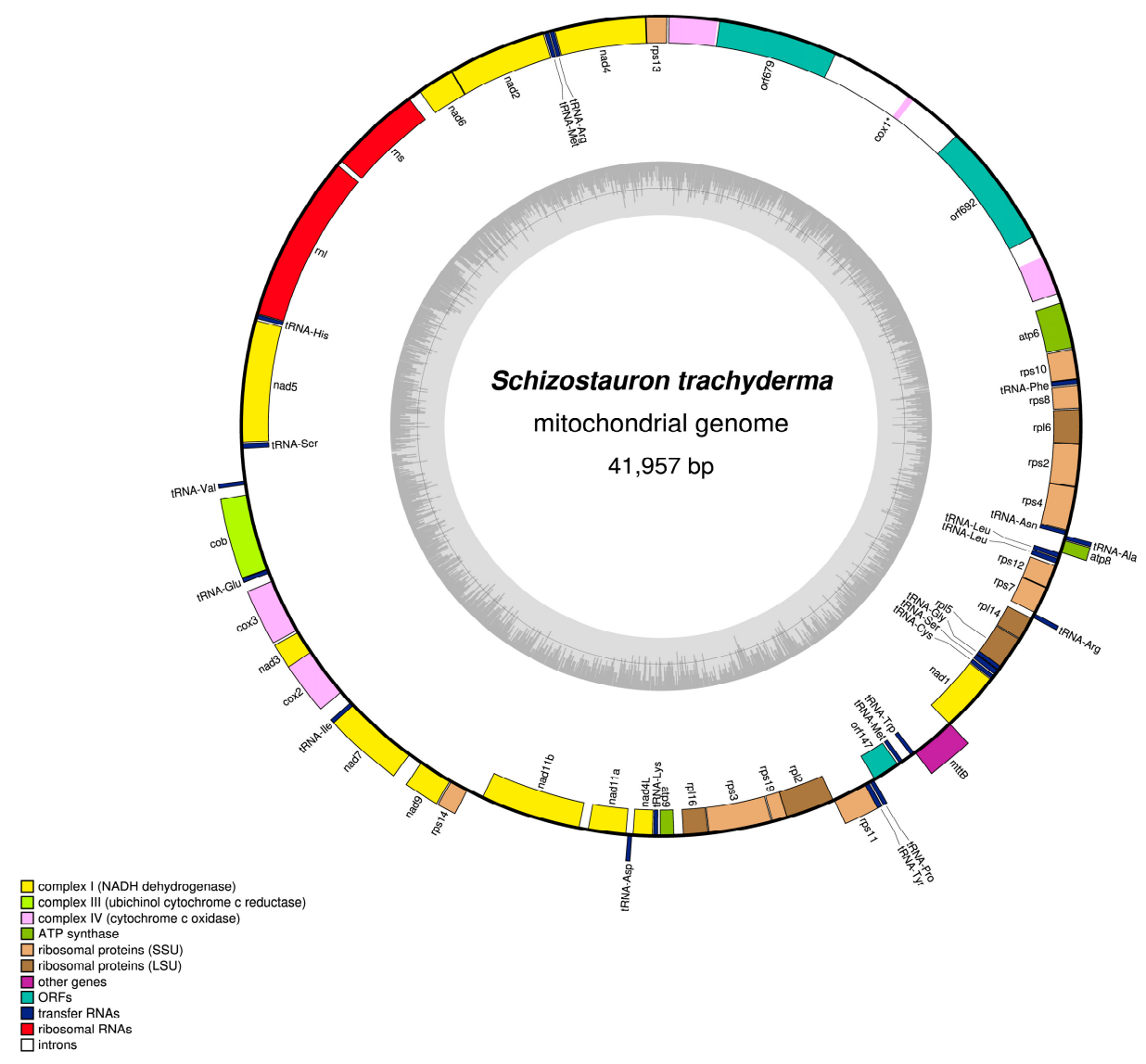

Figure 2. Map of the mitochondrial genome of S. trachyderma.

\subsection{Plastid Genome}

The 187,029 bp plastid genome of S. trachyderma (GenBank accession MZ520768) exhibits the typical quadripartite architecture of diatom genomes (Figure 4). The large single-copy (LSC) region was retrieved with a coverage of 217X. It is 92,894 bp in size and encodes 67 conserved proteins, 15 tRNAs, and 22 open reading frames (ORFs) (Table 1). The closely linked orf104a and orf134a show similarities to $\operatorname{xer} C$ sequences coding for the putative integrases/recombinases. The putative protein of orf134a corresponds to the Cterminal domain of the integrases/recombinases and displays three of the conserved aminoacid residues present in this region (His-289, Arg-292, and Tyr-324), whereas the predicted protein of orf104a corresponds to the $\mathrm{N}$-terminal domain of the integrases/recombinases but lacks the conserved Arg-173 typically present in this region. We speculate that these two ORFs are pseudogenes originating from a single large reading frame that was once coding for a functional protein. The predicted protein of orf110a shows some similarities with serine recombinases $(\operatorname{ser} C)$, but its sequence is incomplete, lacking the C-terminal DNA binding site. The other putative serC (orf224a and orf227a) and xerC (orf299a and orf418a) proteins encoded by the plastid genome of $S$. trachyderma appear complete. In contrast, for example, to the Haslea silbo Gastineau, Hansen, and Mouget plastid genome that recently revealed all serC and $x e r C$ sequences in a single ca. $30 \mathrm{~kb}$ fragment located between $y c f 35$ and $p s b A$ [26], these elements are located in five distinct regions of the S. trachyderma (between the IR and $p s a J, y c f 90$ and $p s b Z, p s b B$ and $r b c S$, atp $A$ and $r p s 14$, tsf and $a t p B)$. 


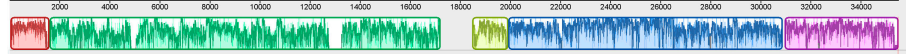

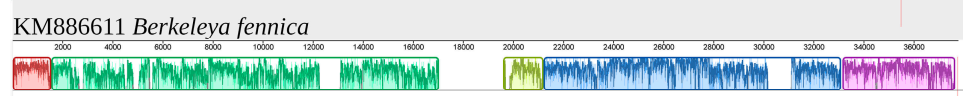

KX889125 Didymosphenia geminata

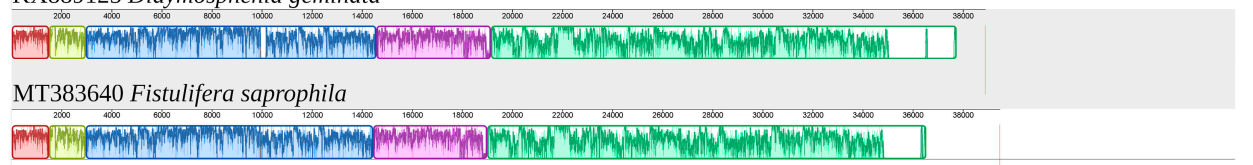

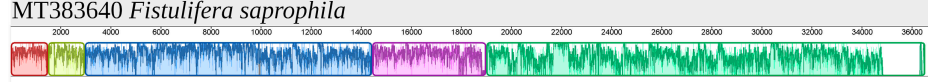

KT363689 Fistulifera solaris

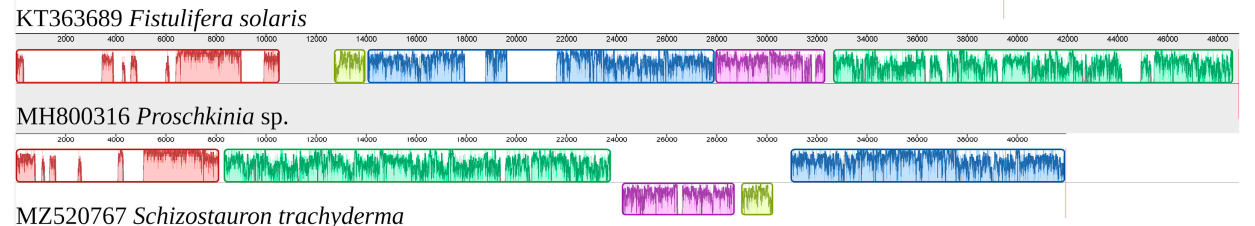

MZ520767 Schizostauron trachyderma

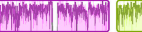

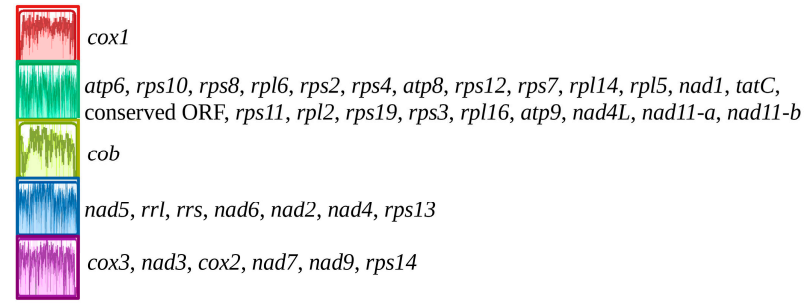

Figure 3. MAUVE alignment of the mitochondrial genomes of Berkeleya fennica (KM886611), Didymosphenia geminata (KX889125), Fistulifera saprophila (MT383640), Fistulifera solaris (KT363689), Proschkinia sp. (MH800316), and Schizostauron trachyderma (MZ520767). The legend below shows the gene content of the blocks of synteny (conserved protein-coding genes and rRNA only).

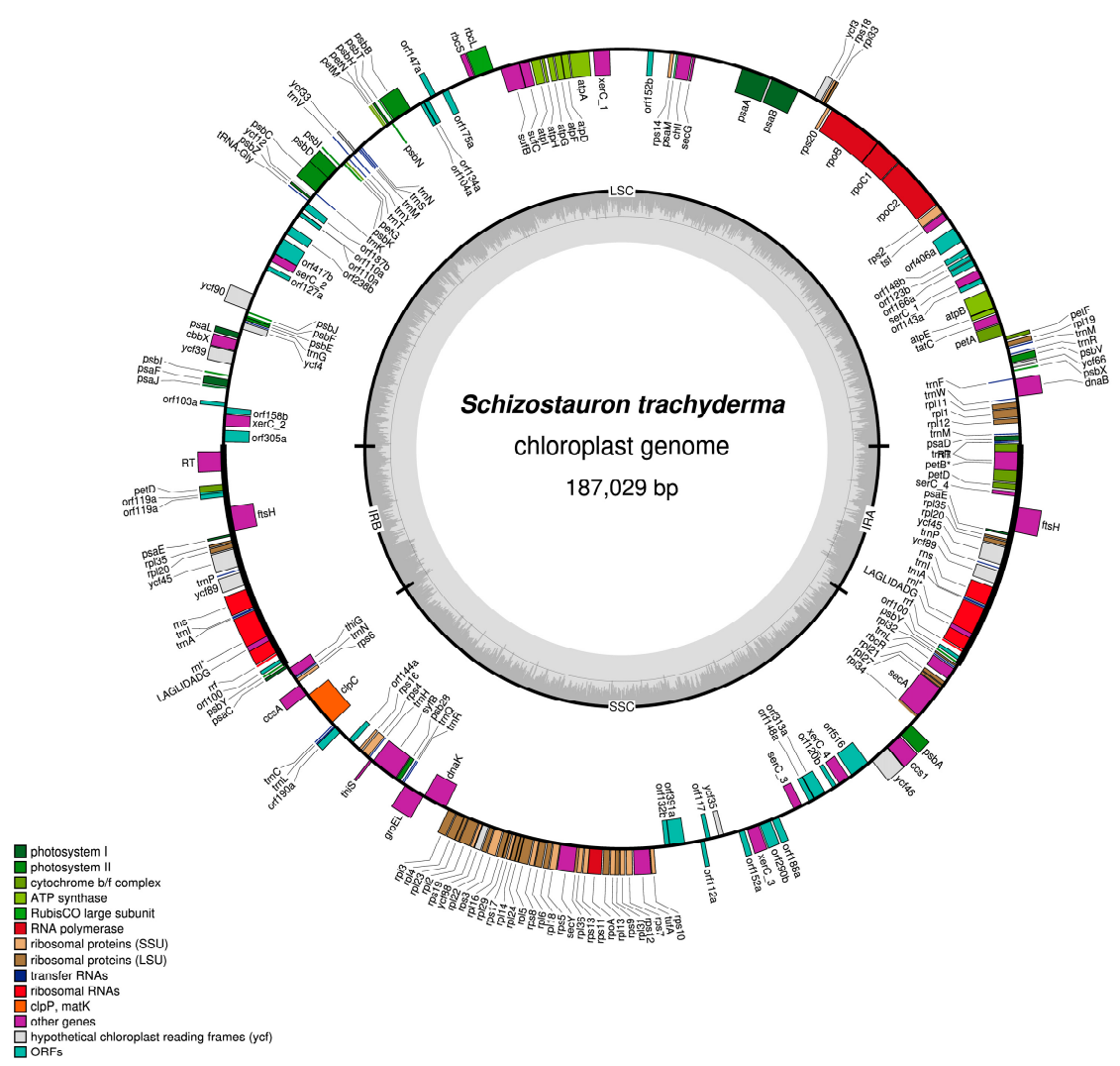

Figure 4. Map of the plastid genome of S. trachyderma. 
Table 1. List of the various ORF found in the mitochondrial and plastid genomes of Schizostauron trachyderma, with the name, position, putative conserved domains, and best blastp result.

\begin{tabular}{|c|c|c|c|}
\hline Name & Position & Putative Conserved Domain & $\begin{array}{l}\text { Best Blastp Result } \\
\text { (E-Value, Identity) }\end{array}$ \\
\hline orf143a & Plastid genome (LSC) & None & $\begin{array}{c}\text { CAA45586.1 from Cylindrotheca closterium }\left(2 \times 10^{-58} \text {, }\right. \\
69.23 \%)\end{array}$ \\
\hline orf $227 \mathrm{a}$ & Plastid genome (LSC) & Putative serine recombinase & AZJ16760.1 from Semiavis robusta $\left(9 \times 10^{-128}, 85.31 \%\right)$ \\
\hline orf166a & Plastid genome (LSC) & None & AZJ16664.1 from Seminavis robusta $\left(2 \times 10^{-24}, 36.88 \%\right)$ \\
\hline orf123b & Plastid genome (LSC) & None & WP_101018572.1 from Olleya sp. $\left(3 \times 10^{-6}, 34.29 \%\right)$ \\
\hline orf148b & Plastid genome (LSC) & None & AXF37983.1 from Seminavis robusta $\left(6 \times 10^{-35}, 66.41 \%\right)$ \\
\hline orf406a & Plastid genome (LSC) & None & CAA45586.1 from Cylindrotheca closterium $(0.0,91.75 \%)$ \\
\hline orf152b & Plastid genome (LSC) & None & $\begin{array}{l}\text { YP_009028997.1 from Cylindrotheca closterium } \\
\qquad\left(2 \times 10^{-33}, 44.30 \%\right)\end{array}$ \\
\hline orf418a & Plastid genome (LSC) & $\begin{array}{l}\text { Putative integrase } \\
\text { recombinase }\end{array}$ & $\begin{array}{c}\text { YP_009686230.1 from Halamphora calidilacuna } \\
\qquad\left(1 \times 10^{-39}, 50.00 \%\right)\end{array}$ \\
\hline orf175a & Plastid genome (LSC) & None & QUW40432.1 from Haslea silbo $\left(5 \times 10^{-21}, 33.88 \%\right)$ \\
\hline orf147a & Plastid genome (LSC) & None & None significant \\
\hline orf134a & Plastid genome (LSC) & $\begin{array}{c}\text { Putative integrase } \\
\text { recombinase (not complete, } \\
\text { contains His-289, Arg-292, } \\
\text { and Tyr-324) }\end{array}$ & $\begin{array}{l}\text { YP_009029005.1 from Cylindrotheca closterium } \\
\qquad\left(5 \times 10^{-63}, 74.63 \%\right)\end{array}$ \\
\hline orf104a & Plastid genome (LSC) & $\begin{array}{l}\text { Putative integrase } \\
\text { recombinase (not complete) }\end{array}$ & $\begin{array}{l}\text { YP_009686252.1 from Halamphora calidilacuna } \\
\qquad\left(2 \times 10^{-27}, 56.31 \%\right)\end{array}$ \\
\hline orf187b & Plastid genome (LSC) & None & HAC63963.1 from Cyanothece sp. $\left(1 \times 10^{-119}, 94.59 \%\right)$ \\
\hline orf110a & Plastid genome (LSC) & $\begin{array}{l}\text { Putative serine recombinase } \\
\text { (not complete in C terminal, } \\
\text { lacks the DNA binding site) }\end{array}$ & $\begin{array}{l}\text { QGW12742.1 from Nanofrustulum shiloi }\left(1 \times 10^{-47} \text {, }\right. \\
85.26 \%)\end{array}$ \\
\hline orf $238 b$ & Plastid genome (LSC) & None & QUS63763.1 from Haslea silbo $\left(3 \times 10^{-23}, 35.02 \%\right)$ \\
\hline orf $417 \mathrm{~b}$ & Plastid genome (LSC) & None & AXF37982.1 from Seminavis robusta $\left(5 \times 10^{-53}, 30.82 \%\right)$ \\
\hline orf224a & Plastid genome (LSC) & Putative serine recombinase & $\begin{array}{l}\text { YP_009496149.1 from Plagiogrammopsis vanheurckii } \\
\qquad\left(6 \times 10^{-135}, 88.79 \%\right)\end{array}$ \\
\hline orf127a & Plastid genome (LSC) & None & None significant \\
\hline orf103a & Plastid genome (LSC) & None & $\begin{array}{l}\text { YP_009028999.1 from Cylindrotheca closterium } \\
\qquad\left(6 \times 10^{-17}, 45.79 \%\right)\end{array}$ \\
\hline orf158b & Plastid genome (LSC) & None & $\begin{array}{c}\text { YP_009029000.1 from Cylindrotheca closterium } \\
\qquad\left(4 \times 10^{-25}, 52.94 \%\right)\end{array}$ \\
\hline orf299a & Plastid genome (LSC) & $\begin{array}{l}\text { Putative integrase } \\
\text { recombinase }\end{array}$ & $\begin{array}{c}\text { YP_009497021.1 from Psammoneis obaidii }\left(7 \times 10^{-151} \text {, }\right. \\
76.77 \%)\end{array}$ \\
\hline orf305a & Plastid genome (LSC) & None & $\begin{array}{c}\text { AZJ16668.1 from Seminavis robusta }\left(2 \times 10^{-154} \text {, }\right. \\
74.43 \%)\end{array}$ \\
\hline orf494a & Plastid genome (IR) & $\begin{array}{l}\text { Putative reverse transcriptase } \\
\text { Putative serine recombinase }\end{array}$ & QGW12739.1 from Nanofrustulum shiloi $(0.0,58.17 \%)$ \\
\hline orf119 & Plastid genome (IR) & $\begin{array}{l}\text { Putative serine recombinase } \\
\text { (not complete in } \mathrm{N} \text { terminal, } \\
\text { lacks most of the presynaptic } \\
\text { site } 1 \text { dimer interface) }\end{array}$ & $\begin{array}{l}\text { QGW12742.1 from Nanofrustulum shiloi }\left(6 \times 10^{-56} \text {, }\right. \\
68.03 \%)\end{array}$ \\
\hline orf139 & Plastid genome (IR) & Putative LAGLIDADG & $\begin{array}{c}\text { AAL34315.1 from Pterosperma cristatum }\left(2 \times 10^{-66}\right. \\
77.34 \%)\end{array}$ \\
\hline orf100 & Plastid genome (IR) & None & AZJ16668.1 from Seminavis robusta $\left(5 \times 10^{-9}, 68.29 \%\right)$ \\
\hline orf190a & Plastid genome (SSC) & None & $\begin{array}{l}\text { YP_009308934.1 from Toxarium undulatum }\left(2 \times 10^{-65} \text {, }\right. \\
61.96 \%)\end{array}$ \\
\hline orf144a & Plastid genome (SSC) & None & None significant \\
\hline orf132b & Plastid genome (SSC) & None & AZJ16659.1 from Seminavis robusta $\left(2 \times 10^{-71}, 90.52 \%\right)$ \\
\hline orf391a & Plastid genome (SSC) & None & $\begin{array}{c}\text { CAA45582.1 from Cylindrotheca fusiformis }\left(2 \times 10^{-168} \text {, }\right. \\
73.63 \%)\end{array}$ \\
\hline orf112a & Plastid genome (SSC) & $\begin{array}{l}\text { Putative integrase } \\
\text { recombinase (not complete in } \\
\mathrm{C} \text { terminal, displays only the } \\
\text { first conserved Arg-173) }\end{array}$ & $\begin{array}{l}\text { YP_009028833.1 from Asterionellopsis glacialis } \\
\qquad\left(1 \times 10^{-47}, 90.00 \%\right)\end{array}$ \\
\hline orf117c & Plastid genome (SSC) & None & $\begin{array}{c}\text { CAA45586.1 from Cylindrotheca closterium }\left(2 \times 10^{-50},\right. \\
74.77 \%)\end{array}$ \\
\hline
\end{tabular}


Table 1. Cont.

\begin{tabular}{|c|c|c|c|}
\hline Name & Position & Putative Conserved Domain & $\begin{array}{l}\text { Best Blastp Result } \\
\text { (E-Value, Identity) }\end{array}$ \\
\hline orf152a & Plastid genome (SSC) & None & HAC63961.1 from Cyanothece sp. $\left(3 \times 10^{-102}, 97.32 \%\right)$ \\
\hline orf317a & Plastid genome (SSC) & $\begin{array}{l}\text { Putative integrase } \\
\text { recombinase }\end{array}$ & $\begin{array}{c}\text { NNF85095.1 from Winogradskyella sp. }\left(4 \times 10^{-88} \text {, }\right. \\
53.01 \%)\end{array}$ \\
\hline orf $290 b$ & Plastid genome (SSC) & None & $\begin{array}{l}\text { YP_009028832.1 from Asterionellopsis glacialis } \\
\qquad\left(8 \times 10^{-61}, 51.33 \%\right)\end{array}$ \\
\hline orf188a & Plastid genome (SSC) & None & AZJ16664.1 from Seminavis robusta $\left(3 \times 10^{-93}, 76.63 \%\right)$ \\
\hline orf234a & Plastid genome (SSC) & Putative serine recombinase & $\begin{array}{l}\text { QWM93463.1 from Tryblionella apiculata }\left(1 \times 10^{-140} \text {, }\right. \\
88.53 \%)\end{array}$ \\
\hline orf148a & Plastid genome (SSC) & None & 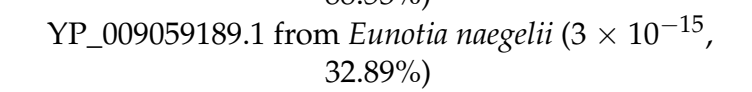 \\
\hline orf313a & Plastid genome (SSC) & None & QUS63950.1 from Haslea silbo $\left(5 \times 10^{-28}, 51.55 \%\right)$ \\
\hline orf120b & Plastid genome (SSC) & None & None significant \\
\hline orf294a & Plastid genome (SSC) & $\begin{array}{l}\text { Putative integrase } \\
\text { recombinase }\end{array}$ & $\begin{array}{c}\text { YP_009495909.1 from Plagiogramma staurophorum } \\
\qquad\left(6 \times 10^{-176}, 83.33 \%\right)\end{array}$ \\
\hline orf516a & Plastid genome (SSC) & None & $\begin{array}{l}\text { CAA45586.1 from Cylindrotheca closterium }\left(2 \times 10^{-92} \text {, }\right. \\
34.58 \%)\end{array}$ \\
\hline orf645 & Mitogenome & Putative reverse transcriptase & $\begin{array}{c}\text { YP_009317775.1 from Navicula ramosissima }(0.0, \\
82.20 \%)\end{array}$ \\
\hline orf690 & Mitogenome & Putative reverse transcriptase & QUS63794.1 from Haslea silbo (0.0, 93.14\%) \\
\hline
\end{tabular}

The small single-copy (SSC) region of $S$. trachyderma was retrieved with a coverage of 222X. It is 59,661 bp in size, and encodes 52 conserved proteins, 7 tRNAs, and 16 non-conserved ORFs, some of which encode putative xerC (orf294a and orf317a) and $\operatorname{serC}$ (orf234a) integrases/recombinases. The predicted protein of orf112a also shows some similarities with $x e r C$ integrases/recombinases but only retains the conserved Arg-173 and lacks the C-terminal region. Note that most of the ORFs encoding putative integrases/recombinases are located in a single block between ycf46 and rps10.

The 17,237 bp inverted repeat (IR) region of the $S$. trachyderma plastid genome was retrieved with a coverage of $428 X$. It encodes nine proteins ( $p s b Y, y c f 89, y c f 45, r p l 20$, rpl35, $p s a E, f t s H, p e t D, p e t B)$, three rRNAs, three tRNAs, and three ORFs. The pet $B$ gene overlaps the IR and LSC regions and contains a 2287-bp group II intron coding for a putative reverse transcriptase (RT, orf494) that shows a high sequence similarity to the RTs identified in the same gene from the diatoms Nanofrustulum shiloi (J.J. Lee, Reimer, and McEnery) Round, Hallsteinsen and Paasche [27] and Halamphora calidilacuna J.G. Stepanek and Kociolek [28] (Table 1). Moreover, the introns of S. trachyderma, N. shiloi, and H. calidilacuna share the same insertion position between codons 7 and 8 of petB. Located between $f t s H$ and petB of S. trachyderma, orf119 shows some similarities to $\operatorname{ser} C$ sequences, but its $\mathrm{N}$-terminal region is incomplete and lacks most of the presynaptic site 1 dimer interface.

The plastid gene for the large subunit ribosomal RNA $(\mathrm{rnl})$ of $S$. trachyderma contains an IB4 intron of $657 \mathrm{bp}$ that encodes a putative LAGLIDADG homing endonuclease (orf139). This intron is inserted between residues 1931 and 1932 relative to the 23S rRNA of Escherichia coli str. K-12, an insertion site that has been frequently observed among green algae $[29,30]$. The predicted protein of orf139 also shows strong similarity with the homing endonucleases identified in green algal IB4 introns at site 1931 [29]. As shown in the LOGO consensus of Figure 5, the typical QWIVGFVDG and PFFE motifs of LAGLIDADG homing endonucleases are highly conserved in the predicted protein of orf139.

\subsection{Comparative Analyses of the Gene Content of Diatom Plastid Genomes}

The gene contents of plastid genomes from all available raphid diatoms were compared with that of S. trachyderma; a comparative table adapted from previous work [31] is displayed as Figure 6. The LSC contains a copy of the tsf gene, which codes for translation elongation factor $\mathrm{T}$ and often seems lost among raphid pennates, found only in 
Fistulifera spp., D. geminata, Gomphoneis minuta var. cassiae Kociolek and Stoermer, and Phaeodactylum tricornutum Bohlin. With the exception of P. tricornutum, all these species belong to the same clade in the plastid multigene phylogeny presented below, but this clade also contains Climaconeis spp., among which this gene was not found [32]. None of the Bacillariaceae (Nitzschia spp., Tryblionella apiculata W.Gregory) or Naviculaceae (Haslea spp., Seminavis robusta D.B. Danielidis and D.G.Mann, Navicula veneta Kützing) present it, nor do Halamphora spp. However, based on previous works [31], this gene is also absent from almost three-quarters of the plastid genomes sequenced, including most centric and araphid pennate species. Schizostauron trachyderma possesses the two genes thiS and thiG, shared by all the other species of the cluster, except Fistulifera spp. Schizostauron trachyderma, which is missing the bas $1 / y c f 42$ gene. This gene is also missing among most Bacillariaceae and Naviculaceae but has been found in Nitzschia supralitorea Lange-Bertalot. Among the species clustered by phylogeny, only D. geminata presents a pseudogene version of bas1/ycf42.
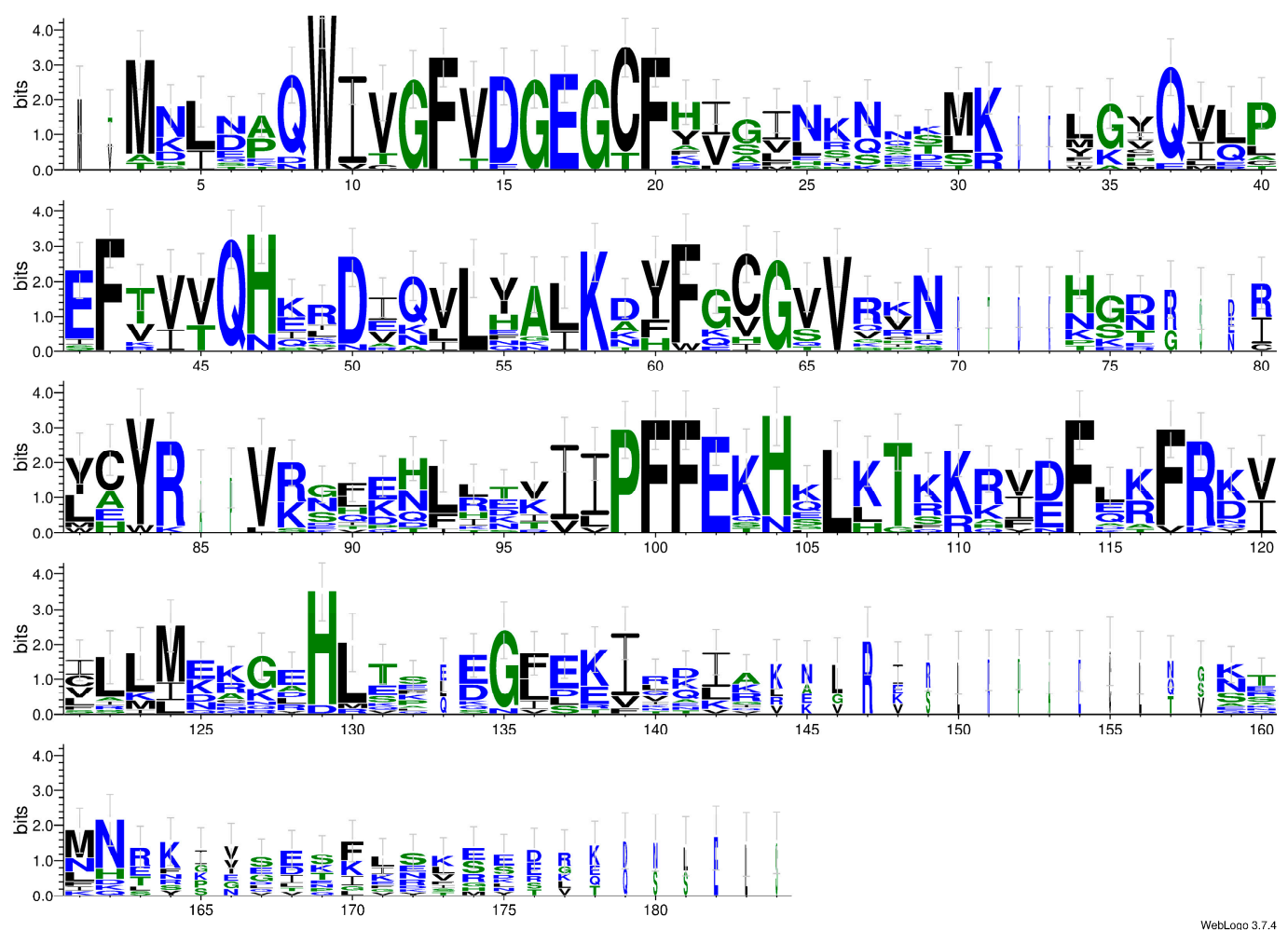

Figure 5. Sequence motifs obtained by aligning LAGLIDADG proteins from Schizostauron trachyderma and 13 sequences from various species of Chlorophyceae corresponding to IB4-L8 LAGLIDADG proteins. The alignment displayed as a LOGO shows the presence of two conserved motifs, QWIVGFVDG and PFFE. 


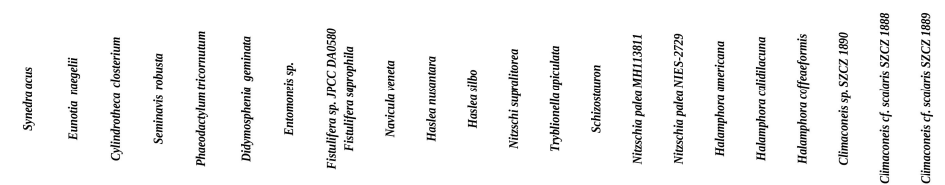

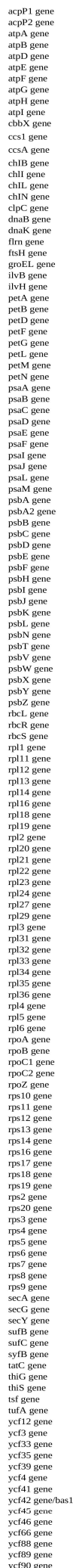
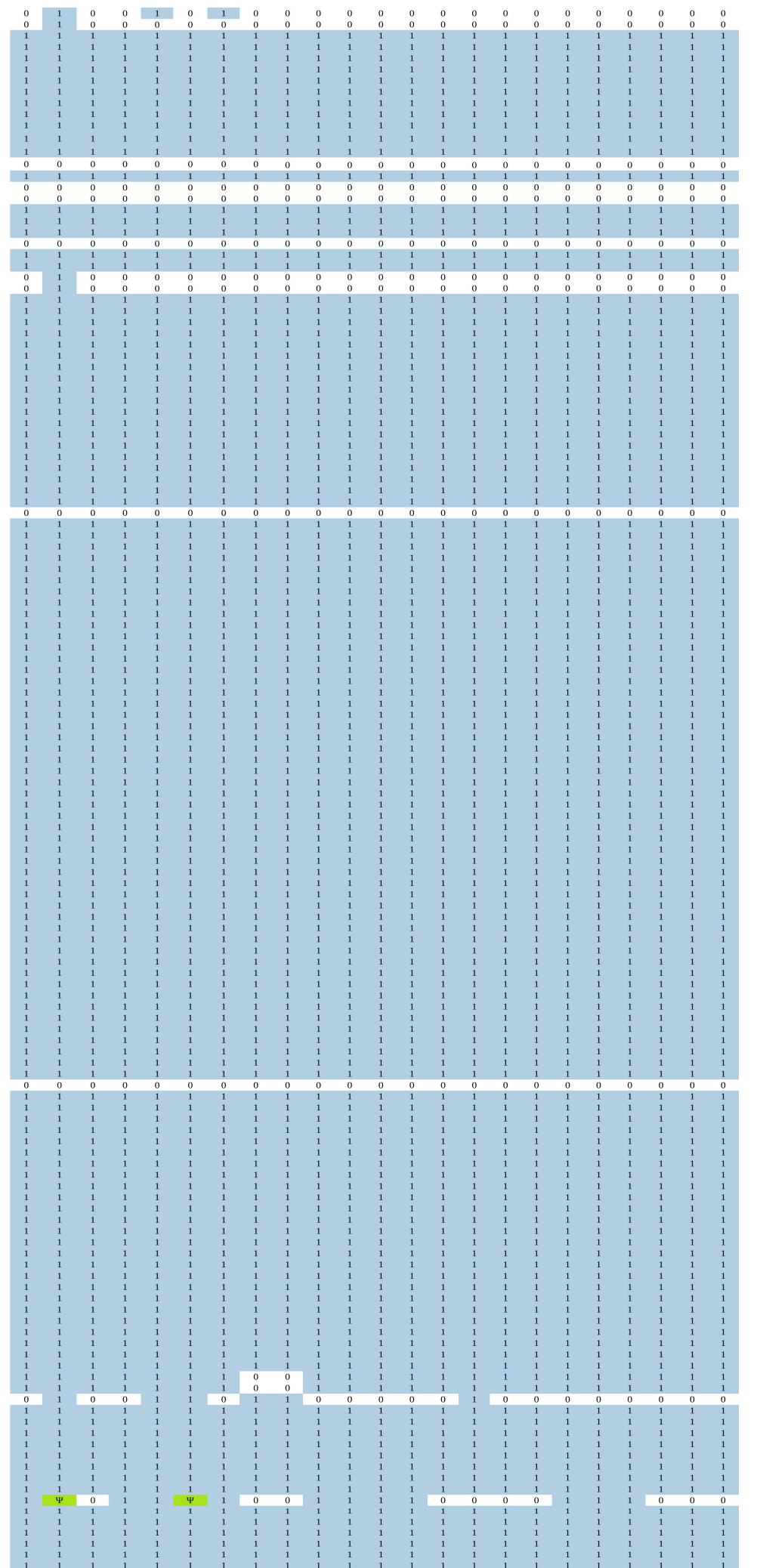

Figure 6. Comparison of the gene composition for the plastid genomes of all the species used in the phylogeny below. A 1 /blue indicates the presence of the gene, a $0 /$ white its lack, and a $\Psi$ /green a pseudogene version of the gene. 


\subsection{Multigene Phylogenies}

We inferred mitochondrial and plastid phylogenomic trees from the concatenated gene sequences of $S$. trachyderma and all raphid pennate diatom organelle genome sequences available in GenBank, using an araphid pennate species as an outgroup. Schizostauron trachyderma proved to be a sister to Fistulifera spp. (and Proschkinia sp. in the case of the mitochondrial data) in all trees (Figures 7 and 8), a result consistent with recently reported phylogenetic analyses $[5,20,21]$. Note that Fistulifera and Proschkinia taxa present a distinctive occluded pore on their valves, called a fistula. Interestingly, this feature is not found on Schizostauron valves.

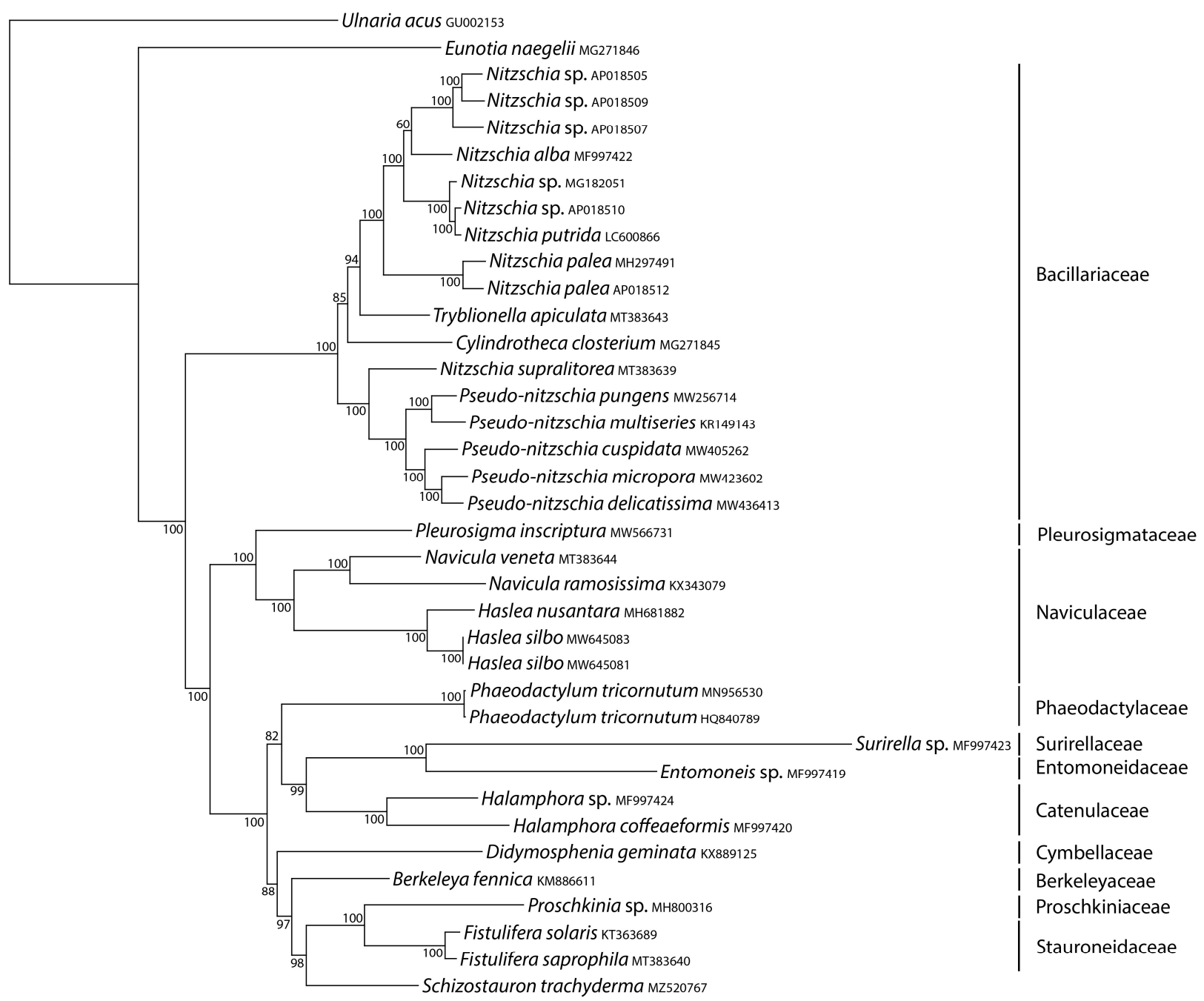

0.50

Figure 7. Maximum likelihood phylogeny inferred from an alignment of concatenated protein-coding genes from 37 mitochondrial genomes of diatoms, including that of S. trachyderma. The araphid species Ulnaria acus served as an outgroup in this analysis. The best scoring RAxML tree (log likelihood $=-414,469.369802)$ is presented with bootstrap support values denoted on the nodes. The scale bar indicates the number of substitutions per site. The araphid species Ulnaria acus is used as an outgroup. 


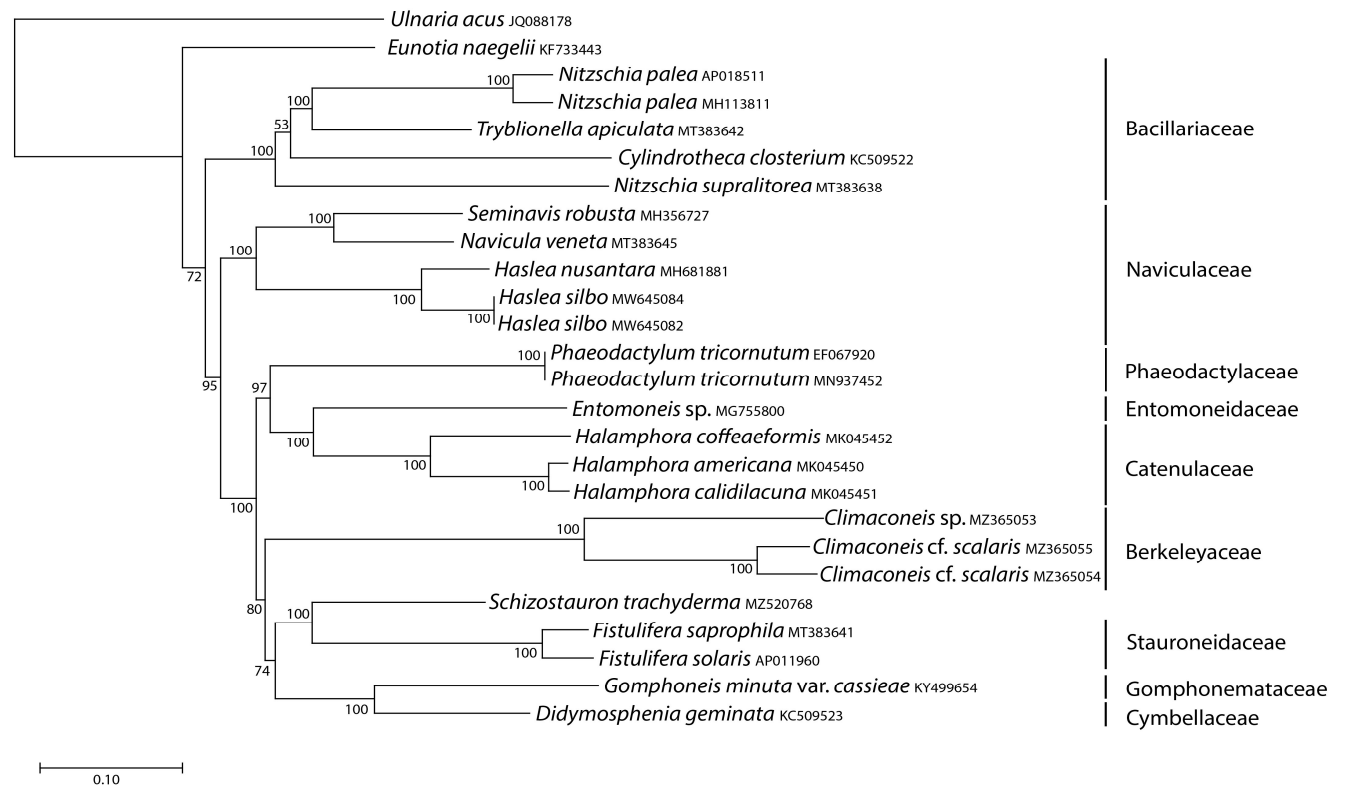

Figure 8. Maximum likelihood phylogeny inferred from an alignment of concatenated protein-coding genes from 26 plastid genomes of diatoms, including that of S. trachyderma. The araphid species Ulnaria acus served as an outgroup in this analysis. The best scoring RAxML tree (log likelihood $=-878,702.878358$ ) is presented with bootstrap support values denoted on the nodes. The scale bar indicates the number of substitutions per site.

The mitogenome-based tree (Figure 7) is the most taxon-rich of both trees, mostly because of the availability of several mitogenomes from two genera of the Bacillariaceae (Nitzschia and Pseudo-nitzschia). In addition to the Schizostauron, Fistulifera, and Proschkinia association mentioned above, the mitochondrial tree revealed that $S$. trachyderma was part of a larger clade including Surirella sp., Halamphora spp., Entomoneis sp., P. tricornutum, D. geminata, and B. fennica. The Naviculaceae formed a monophyletic group sister to a clade containing the rest of the raphid pennates.

Although the plastome-based phylogenetic tree (Figure 8) has a smaller taxon sampling, its topology is similar to the mitochondrial tree. The $S$. trachyderma also proved to be a sister of Fistulifera spp. and these taxa were recovered in a clade that also includes $G$. minuta var. cassiae, D. geminata, and Climaconeis spp.

\section{Discussion}

The multigene phylogenetic analyses presented here confirm the close evolutionary relationship between S. trachyderma and fistula-bearing taxa such as Fistulifera spp. and Proschkinia sp. This phylogenetic association could be improved and refined in future studies of additional organellar genomes of monoraphid genera such as Astartiella, Madinithidium, Karayevia, and Kolbesia. Based on recently published analyses, we expect these genera to be related to Schizostauron, as these stauroneid monoraphid taxa form a monophyletic clade sister to Fistulifera and Proschkinia, which is nested in a clade comprising genera belonging to Stauroneidaceae, such as Stauroneis, Craticula, Sternimirus, Dorofeyukea, Parlibellus, and Prestauroneis $[5,17,18,20,21]$. It is possible that the close relationship of stauroneid biraphid genera to stauroneid monoraphid genera is a result of insufficient taxon sampling or inadequate or insufficient choice of molecular markers. Genomic data from these taxa might reveal signature characters of specific monoraphid clades and could provide insights to the independent losses of the raphe on one valve.

The S. trachyderma plastid genome revealed features that were rarely or never observed among diatoms. The finding of a group II intron overlapping the IR and the LSC regions in the petB gene is certainly noteworthy, as is the observation of a LAGLIDADG homing endonuclease in the $r n l$ gene. To our knowledge, genes encoding this type of homing 
endonuclease have so far been found only in the IA3 $\mathrm{rnl}$ intron of the S. robusta plastid genome (annotated as I-SroI, accession AZJ16657.1 [33] and in a cox1 intron of the $N$. supralitorea mitogenome, accession QWM93242.1 [34]. As in a few other diatom species [31], our analyses of conserved domains in the putative $\operatorname{ser} C$ and $x e r C$ genes of $S$. trachyderma suggest that some of them are pseudogenes. As interesting as both the above-mentioned results are for the study of mobile DNA, we refrain from speculating on any explanation regarding their presence/absence among different taxa.

Our study, the first of its kind on a monoraphid diatom, should soon be followed by more organellar genome sequencing on other species belonging to genera such as the aforementioned Parlibellus, Stauroneis, Astartiella, and Madinithidium.

\section{Materials and Methods}

\subsection{Isolation and Cultivation of the Biological Material}

The strain SZCZE1420 of S. trachyderma was isolated from an environmental sample collected in February 2015 near Jeddah on the Red Sea coast of Saudi Arabia $\left(21.7561^{\circ} \mathrm{N}\right.$ $39.05^{\circ} \mathrm{E}$ ). A monoclonal culture was established using glass micropipettes and inverted light microscopy (Nikon eclipse TS100) following Andersen and Kawachi [35]. The culture is kept in artificial $\mathrm{f} / 2$ culture medium [36] in a growth chamber (Biogenet, Poland) with $12 \mathrm{~h}$ day $\left(20^{\circ} \mathrm{C}\right): 12 \mathrm{~h}$ night $\left(18^{\circ} \mathrm{C}\right)$ cycles under $100 \mu \mathrm{mol}$ photons $\mathrm{m}^{-2} \mathrm{~s}^{-1}$ illumination.

\subsection{Light and Scanning Electron Microscopy}

Diatom pellets were centrifuged at $900 \times g$ for $5 \mathrm{~min}$ and treated with $37 \%$ hydrogen peroxide for $3 \mathrm{~h}$ at $170{ }^{\circ} \mathrm{C}$ to remove organic components of frustules. The residual material was washed 7-10 times with distilled water. For light microscopy (LM), cleaned frustules were pipetted onto coverslips, air-dried, and mounted on glass slides with synthetic diatom resin Naphrax ${ }^{\circledR}$ (Brunel Microscopes Ltd., Chippenham, UK). LM microphotographs of cleaned frustules and plastids were taken at the University of Szczecin by means of a Zeiss Axio Scope A1 (Carl Zeiss, Jena, Germany) with an oil immersion lens Zeiss Plan-Apochromat 100 $\times / 1.40$ Oil M27 (Carl Zeiss, Jena, Germany) using a Canon EOS 500D camera (Canon, Tokyo, Japan) with the Canon EOS Utility software. For scanning electron microscopy (SEM), the cleaned material was pipetted onto a Whatman Nuclepore polycarbonate membrane filter with $5 \mu \mathrm{m}$ pores (cat. no. 110613, Maidstone, UK) and mounted onto aluminium stubs. SEM observations were performed using a Hitachi SU8010 (Tokyo, Japan) at the University of Rzeszów (Poland), Faculty of Agriculture and Biology.

\subsection{DNA Sequencing, Annotation, Whole Genome Alignments and Phylogeny}

The SZCZE1420 clone of $S$. trachyderma was grown as described above, and cells in the exponential growth phase were harvested by centrifugation. DNA was extracted according to Doyle and Doyle [37]. Sequencing took place on the DNBseq platform at the Beijing Genomics Institute (Shenzhen). A total of 40 million 150-bp paired-end reads were assembled using SPAdes 3.14 .0 [38] with a k-mer of 125. Contigs were verified and merged using Consed [39]. The genes were identified as previously described [34,40]. Maps of organellar genomes were prepared using the OGDRAW v1.3.1 online platform [41]. Whole mitogenome alignment was performed with progressive Mauve [42] after removing the second copy of the IR sequence in the plastid genomes. LOGO consensus sequences of LAGLIDADG homing endonucleases were obtained online with WebLogo3 [43]. For multigene phylogenies, mitochondrial and plastid protein-coding genes were extracted, separately concatenated, and aligned with orthologous diatom gene sequences obtained from GenBank. The mitochondrial and plastid multigene phylogeny were conducted on 37 and 26 taxa, respectively, including S. trachyderma and U. acus in both cases. The sampling was restricted to raphid pennate species, except for the araphid species Ulnaria acus (Kützing) Aboal that served as an outgroup. Phylogenetic analyses were conducted using RaxML version 8 [44], with the GTR + I + G model and 1000 bootstrap replications. Genes were concatenated and aligned using MAFFT 7 [45] before the alignments 
were trimmed by trimAl v1.2 [46]. The evolution model was chosen using jModelTest2 v2.1.10 [47] on the trimmed alignments. The number of concatenated genes was 35 for the mitochondrial-inferred phylogeny and 127 for the plastid-inferred phylogeny. The final sizes of the alignments as calculated by trimAl were $22140 \mathrm{bp}$ for the mitochondrial genes alignment and $86587 \mathrm{bp}$ for the plastid genes alignment. The evolution model was used as a single model across the entire alignment.

Author Contributions: Conceptualization, E.G. and R.G.; funding acquisition, A.W.; investigation, E.G., R.G., N.A.D., O.I.D., M.P.A., J.S.M.S., C.L., M.T. and A.W.; methodology, E.G. and R.G.; project administration, A.W.; supervision, R.G. and A.W.; visualization, E.G. and R.G.; writing-original draft, E.G. and R.G.; writing-review and editing, N.A.D., O.I.D., M.P.A., J.S.M.S., C.L., M.T. and A.W. All authors have read and agreed to the published version of the manuscript.

Funding: This research was funded by the Polish National Science Centre in Cracow, grant preludium NCN 2016/23/NZ8/02796. This study was also supported by the European Commission under the Horizon 2020 Research and Innovation Program GHaNA (The Genus Haslea, New marine resources for blue biotechnology and aquaculture, grant agreement No (734708/GHANA/H2020-MSCA-RISE2016) J.-L.M.), and also the 2017-2022 research funds granted for implementation of a co-financed international research project from the Polish Ministry of Science and Higher Education.

Institutional Review Board Statement: Not applicable.

Informed Consent Statement: Not applicable.

Data Availability Statement: Molecular data have all been deposited to GenBank. Data are also available on Zenodo with the following link: https:/ / doi.org/10.5281/zenodo.5361687 (accessed on 1 September 2021).

Conflicts of Interest: The authors declare no conflict of interest.

\section{References}

1. Grunow, A. Diatomeen auf Sargassum von Honduras, gesammelt von Linding. Nova Hedwigia 1867, 6, 1-37.

2. Ross, R. The diatom genus Capartogramma and the identity of Schizostauron. Bull. Br. Mus. Nat. Hist. Bot. 1963, 3, 49-92.

3. Riaux-Gobin, C.; Compére, P.; Hinz, F.; Ector, L. Achnanthes citronella, A. trachyderma comb. nov. Bacillariophyta) and allied taxa pertaining to the same morphological group. Phytotaxa 2015, 227, 101-119. [CrossRef]

4. Davidovich, N.A.; Davidovich, O.I.; Witkowski, A.; Li, C.L.; Dąbek, P.; Mann, D.G.; Zgłobicka, I.; Kurzydłowski, K.J.; Gusev, E.S.; Górecka, E.; et al. Sexual reproduction in Schizostauron (Bacillariophyta) and a preliminary phylogeny of the genus. Phycologia 2017, 56, 77-93. [CrossRef]

5. Górecka, E.; Ashworth, M.P.; Davidovich, N.; Davidovich, O.; Dąbek, P.; Sabir, J.S.; Witkowski, A. Multigene phylogenetic data place monoraphid diatoms Schizostauron and Astartiella along with other fistula bearing genera in the Stauroneidaceae. J. Phycol. 2021, 57, 1472-1491, online ahead of print. [CrossRef]

6. Schütt, F. Bacillariales. In Die Natürlichen Pflanzenfamilien, 1(1b); Engler, A., Prantl, K., Eds.; W. Englemann: Leipzig, Germany, 1896; pp. 31-153.

7. Hustedt, F. Bacillariophyta (Diatomeae). In Die Sübwasser-Flora Mitteleuropas, Zweite Auflage. Heft 10; Pascher, A., Ed.; Gustav Fischer: Jena, Germany, 1930; pp. 1-466.

8. Round, F.E.; Crawford, R.M.; Mann, D.G. The Diatoms. Biology and Morphology of the Genera; Cambridge University Press: Cambridge, UK, 1990; pp. 1-747.

9. Williams, D.; Kociolek, J.P. An Overview of Diatom Classification with Some Prospects for the Future. In The Diatom World; Seckbach, J., Kociolek, J.P., Eds.; Springer: Dordrecht, The Netherlands, 2011; pp. 47-91.

10. Round, F.E.; Bukhtiyarova, L. Revision of Achnanthes sensu lato section Marginulatae Buht. sect. nov. of Achnanthidium Kutz. Diatom Res. 1996, 11, 1-30.

11. Round, F.E.; Bukhtiyarova, L. Four new genera based on Achnanthes (Achnanthidium) together with a re-definition of Achnanthidium. Diatom Res. 1996, 11, 345-361. [CrossRef]

12. Round, F.E.; Basson, P.W. A new monoraphid diatom genus (Pogoneis) from Bahrain and the transfer of previously described species A. hungarica \& A. taeniata to new genera. Diatom Res. 1997, 12, 71-81.

13. De Stefano, M.; Marino, D. Morphology and taxonomy of Amphicocconeis gen. nov. (Achnanthales, Bacillariophyceae, Bacillariophyta) with considerations on its relationship to other monoraphid diatom genera. Eur. J. Phycol. 2003, 38, 361-370. [CrossRef]

14. Riaux-Gobin, C.; Witkowski, A.; Ruppel, M. Scalariella a new genus of monoraphid diatom (Bacillariophyta) with a bipolar distribution. Fottea 2012, 12, 13-25. [CrossRef] 
15. Kulikovskiy, M.; Lange-Bertalot, H.; Witkowski, A. Gliwiczia gen. nov., a new achnanthoid diatom genus with description of four species new for science. Phytotaxa 2013, 109, 1-16. [CrossRef]

16. Desrosiers, C.; Witkowski, A.; Riaux-Gobin, C.; Zglobicka, I.; Kurzydlowski, K.J.; Eulin, A.; Leflaive, J.; Ten-Hage, L. Madinithidium gen. nov. (Bacillariophyceae), a new monoraphid diatom genus from the tropical marine coastal zone. Phycologia 2014, 53, 583-592. [CrossRef]

17. Kulikovskiy, M.; Maltsev, Y.; Andreeva, S.; Glushchenko, A.; Gusev, E.; Podunay, Y.; Ludwig, T.V.; Tusset, E.; Kociolek, J.P. Description of a new diatom genus Dorofeyukea gen. nov. with remarks on phylogeny of the family Stauroneidaceae. J. Phycol. 2019, 55, 173-185. [CrossRef] [PubMed]

18. Witkowski, A.; Li, C.; Zgłobicka, I.; Yu, S.X.; Ashworth, M.; Dąbek, P.; Qin, S.; Tang, C.; Krzywda, M.; Ruppel, M.; et al. Multigene assessment of biodiversity of diatom (Bacillariophyceae) assemblages from the littoral zone of the Bohai and Yellow Seas in Yantai Region of Northeast China with some remarks on ubiquitous taxa. J. Coast. Res. 2016, 74, 166-195. [CrossRef]

19. Gastineau, R.; Kim, S.Y.; Lemieux, C.; Turmel, M.; Witkowski, A.; Park, J.G.; Kim, B.S.; Mann, D.G.; Theriot, E.C. Complete mitochondrial genome of a rare diatom (Bacillariophyta) Proschkinia and its phylogenetic and taxonomic implications. Mitochondrial DNA Part B Resour. 2019, 4, 25-26. [CrossRef] [PubMed]

20. Majewska, R.; Bosak, S.; Frankovich, T.A.; Ashworth, M.P.; Sullivan, M.J.; Robinson, N.J.; Lazo-Wasem, E.A.; Pinou, T.; Nel, R.; Manning, S.R.; et al. Six new epibiotic Proschkinia (Bacillariophyta) species and new insights into the genus phylogeny. Eur. J. Phycol. 2019, 54, 609-631. [CrossRef]

21. Kim, S.Y.; Witkowski, A.; Park, J.G.; Gastineau, R.; Ashworth, M.P.; Kim, B.S.; Mann, D.G.; Li, C.L.; Igersheim, A.; Płociński, T.; et al. The taxonomy and diversity of Proschkinia (Bacillariophyta), a common but enigmatic genus from marine coasts. J. Phycol. 2020, 56, 953-978. [CrossRef]

22. Kulikovskiy, M.S.; Andreeva, S.A.; Gusev, E.S.; Kuznetsova, I.V.; Annenkova, N.V. Molecular phylogeny of monoraphid diatoms and raphe significance in evolution and taxonomy. Biol. Bull. 2016, 43, 398-407. [CrossRef]

23. Ashworth, M.P.; Lobbann, C.S.; Witkowski, A.; Theriot, E.C.; Sabir, M.J.; Baeshen, M.N.; Hajarah, N.H.; Baeshen, N.A.; Sabir, J.S.; Jansen, R.K. Molecular and Morphological Investigations of the Stauros-bearing, Raphid Pennate Diatoms (Bacillariophyceae): Craspedostauros E.J. Cox, and Staurotropis T.B.B. Paddock, and their Relationship to the Rest of the Mastogloiales. Protist 2017, 168, 48-70. [CrossRef] [PubMed]

24. Riaux-Gobin, C.; Saenz-Agudelo, P.; Górecka, E.; Witkowski, A.; Daniszewska-Kowalczyk, G.; Ector, L. Cocconeis vaiamanuensis sp. nov. (Bacillariophyceae) from Raivavae (South Pacific) and allied taxa: Ultrastructural specificities and remarks about the polyphyletic genus Cocconeis Ehrenberg. Mar. Biodivers. 2021, 51, 1-23. [CrossRef]

25. Pogoda, C.S.; Keepers, K.G.; Hamsher, S.E.; Stepanek, J.G.; Kane, N.C.; Kociolek, J.P. Comparative analysis of the mitochondrial genomes of six newly sequenced diatoms reveals group II introns in the barcoding region of cox1. Mitochondrial DNA Part A 2018, 30, 43-51. [CrossRef]

26. Gastineau, R.; Hansen, G.; Poulin, M.; Lemieux, C.; Turmel, M.; Bardeau, J.-F.; Leignel, V.; Hardivillier, Y.; Morançais, M.; Fleurence, J.; et al. Haslea silbo, A Novel Cosmopolitan Species of Blue Diatoms. Biology 2021, 10, 328. [CrossRef]

27. Li, C.; Gastineau, R.; Turmel, M.; Witkowski, A.; Otis, C.; Car, A.; Lemieux, C. Complete chloroplast genome of the tiny marine diatom Nanofrustulum shiloi (Bacillariophyta) from the Adriatic Sea. Mitochondrial DNA Part B 2019, 4, 3374-3376. [CrossRef]

28. Hamsher, S.E.; Keepers, K.G.; Pogoda, C.S.; Stepanek, J.G.; Kane, N.C.; Kociolek, J.P. Extensive chloroplast genome rearrangement amongst three closely related Halamphora spp. (Bacillariophyceae), and evidence for rapid evolution as compared to land plants. PLoS ONE 2019, 14, e0217824. [CrossRef]

29. Lucas, P.; Otis, C.; Mercier, J.P.; Turmel, M.; Lemieux, C. Rapid evolution of the DNA-binding site in LAGLIDADG homing endonucleases. Nucleic Acids Res. 2001, 29, 960-969. [CrossRef]

30. Turmel, M.; Lemieux, C. Evolution of the Plastid Genome in Green Algae. Adv. Bot. Res. 2018, 85, 157-193.

31. Yu, M.; Ashworth, M.P.; Hajrah, N.H.; Khiyami, M.A.; Sabir, M.J.; Alhebshi, A.M.; Al-Malki, A.L.; Sabir, J.S.M.; Theriot, E.C.; Jansen, R.K. Evolution of the plastid genomes in diatoms. Adv. Bot. Res. 2018, 85, 129-155.

32. Gastineau, R.; Davidovich, N.A.; Davidovich, O.I.; Lemieux, C.; Turmel, M.; Wróbel, R.J.; Witkowski, A. Extreme Enlargement of the Inverted Repeat Region in the Plastid Genomes of Diatoms from the Genus Climaconeis. Int. J. Mol. Sci. 2021, $22,7155$. [CrossRef] [PubMed]

33. Brembu, T.; Winge, P.; Tooming-Klunderud, A.; Nederbragt, A.J.; Jakobsen, K.S.; Bones, A.M. The chloroplast genome of the diatom Seminavis robusta: New features introduced through multiple mechanisms of horizontal gene transfer. Mar. Genom. 2014, 16, 17-27. [CrossRef]

34. Gastineau, R.; Hamedi, C.; Baba Hamed, M.B.; Abi-Ayad, S.-M.E.-A.; Bąk, M.; Lemieux, C.; Turmel, M.; Dobosz, S.; Wróbel, R.J.; Kierzek, A.; et al. Morphological and molecular identification reveals that waters from an isolated oasis in Tamanrasset (extreme South of Algerian Sahara) are colonized by opportunistic and pollution-tolerant diatom species. Ecol. Ind. 2021, $121,107104$. [CrossRef]

35. Andersen, R.A.; Kawachi, M. Traditional microalgae isolation techniques. In Algal Culturing Techniques; Andersen, R.A., Ed.; Elsevier: London, UK, 2005; pp. 83-100.

36. Guillard, R.R.L. Culture of phytoplankton for feeding marine invertebrates. In Culture of Marine Invertebrate Animals; Smith, W.L., Chanley, M.H., Eds.; Plenum Press: New York, NY, USA, 1975; pp. $29-60$.

37. Doyle, J.J.; Doyle, J.L. Isolation of plant DNA from fresh tissue. Focus 1990, 12, 13-15. 
38. Bankevich, A.; Nurk, S.; Antipov, D.; Gurevich, A.A.; Dvorkin, M.; Kulikov, A.S.; Lesin, V.M.; Nikolenko, S.I.; Pham, S.; Prjibelski, A.D.; et al. SPAdes: A new genome assembly algorithm and its applications to single-cell sequencing. J. Comput. Biol. 2012, 19, 455-477. [CrossRef] [PubMed]

39. Gordon, D.; Green, P. Consed: A graphical editor for next-generation sequencing. Bioinformatics 2013, 29, 2936-2937. [CrossRef] [PubMed]

40. Turmel, M.; Otis, C.; Lemieux, C. Divergent copies of the large inverted repeat in the chloroplast genomes of ulvophycean green algae. Sci. Rep. 2017, 7, 994. [CrossRef]

41. Greiner, S.; Lehwark, P.; Bock, R. OrganellarGenomeDRAW (OGDRAW) version 1.3.1: Expanded toolkit for the graphical visualization of organellar genomes. Nucleic Acids Res. 2019, 47, W59-W64. [CrossRef] [PubMed]

42. Darling, A.E.; Mau, B.; Perna, N.T. progressiveMauve: Multiple genome alignment with gene gain, loss and rearrangement. PLoS ONE 2010, 5, e11147. [CrossRef] [PubMed]

43. Crooks, G.E.; Hon, G.; Chandonia, J.-M.; Brenner, S.E. WebLogo: A sequence logo generator. Genome Res. 2004, 14, 1188-1190. [CrossRef] [PubMed]

44. Stamatakis, A. RAxML Version 8: A tool for phylogenetic analysis and post-analysis of large phylogenies. Bioinformatics 2014, 30, 1312-1313. [CrossRef]

45. Katoh, K.; Standley, D.M. A simple method to control over-alignment in the MAFFT multiple sequence alignment program. Bioinformatics 2016, 32, 1933-1942. [CrossRef]

46. Capella-Gutiérrez, S.; Silla-Martínez, J.M.; Gabaldón, T. trimAl: A tool for automated alignment trimming in large-scale phylogenetic analyses. Bioinformatics 2009, 25, 1972-1973. [CrossRef]

47. Darriba, D.; Taboada, G.L.; Doallo, R.; Posada, D. jModelTest 2: More models, new heuristics and parallel computing. Nature Met. 2012, 9, 772. [CrossRef] 